\title{
ARBITRATION AND PUBLIC POLICY IN BRAZIL: A STUDY BASED ON 'LULA CASE'
}

Carolina Barreira Lins

\author{
LL.M. in Energy and Natural Resources Law in Queen Mary \\ University of London, Reino Unido. \\ linscaroli@gmail.com \\ Received: 2015-10-27. Accepted: 2016-09-18.
}

\begin{abstract}
This work examines the subject of jurisdiction and arbitrability of issues related to energy and natural resources in the world, in order to enhance the arbitration institute in Brazil. The study is based on a recent case pending in Brazilian courts, named "Lula case", which refer to a dispute between the State and concessionaires that grant the right to explore and produce oil and gas in a determined area. The presence of arbitration clauses in the concession contracts for exploration and production of oil and gas in Brazil raises questions related to the disposability of the rights concerned. It is paramount to set benchmarks on arbitral tribunals' power to decide on these matters and to define to what extent arbitral awards may defy public policy, national sovereignty over natural resources and national courts' jurisdiction to render decisions in this regard. Otherwise, the randomness of judicial decisions makes the arbitration clause ineffective. Moreover, the Lula case arises substantive issues related to the necessity to protect investors in the oil and gas industry, since acts arguably connect to the State policy power may cause damages to the private parties. The work critically examines the decision given by national courts so far and proposes an international approach to face situations involving the State and the necessity to protect investors in the oil and gas industry.
\end{abstract}

Keywords: Legal status of aliens in Brazil - Human rights - Brazilian Constitutions

\section{INTRODUCTION}

Brazilian Arbitration Act $^{1}$ (BAA) was enacted over 20 years ago.

1 Brazilian Law 9,307/96. 
National courts were initially reluctant to apply it, because of arguments from part of the legal community ${ }^{2}$ that it was unconstitutional, by allowing parties to waive the inalienable right to seek justice in the courts, protected by the Federal Constitution. This controversy existed until the Federal Supreme Court upheld the constitutionality of key articles of the law in 2001, under the argument that although a law may not prevent parties from accessing the judiciary, parties can contractually waive this right in matters involving disposable pecuniary rights ${ }^{3}$.

In 2002, Brazil ratified the New York Convention ${ }^{4}$ (NYC) and the procedure for recognizing and enforcing awards has subsequently been expedited by a December 2004 Constitutional amendment that shifted original jurisdiction over recognition of foreign awards (judicial and arbitral) from the Federal Supreme Court to the Superior Tribunal of Justice (STJ) ${ }^{5}$, setting the decision free from the uncertainties associated with constitutional law ${ }^{6}$.

The BAA reflects the influence of the UNCITRAL Model Law on Commercial Arbitration ${ }^{7}$ (UNCITRAL Model Law) and of the NYC. The jurisprudential evolution shows that gradual advances have been occurring in recent years. National courts have increasingly abstained from interfering in the merits of arbitral awards and the STJ has been increasingly supporting the recognition of foreign arbitral awards, as well as the validity of arbitration clauses ${ }^{8}$.

By following the $\mathrm{NYC}^{9}$, Article 39 of BAA states that a request for the recognition or enforcement of a foreign arbitral award shall be

2 Marcelo A Muriel, 'A Arbitragem Frente Ao Judiciário Brasileiro' (2004) 1 Revista Brasileira de Arbitragem 27, 28.

3 Brazilian Federal Supreme Court, sitting en banc, Regimental Appeal in Contested Foreign Judgment no. 5206, Reporting Justice Sepúlveda Pertence, judged on December 12, 2001, published in the DJ (Court Reporter) of April 30, 2004

4 The Convention on the Recognition and Enforcement of Foreign Arbitral Awards (adopted 10 June 1958 entered into force 07 June 1959) 330 UNTS 38 (1968)

5 The Superior Tribunal de Justiça (STJ) is the highest court for non-constitutional matters, with responsibility for harmonizing interpretation of federal law by the state and regional federal courts of appeal.

6 Alexis Mourre, 'Perspectives of International Arbitration in Latin America' (2006) 17 Am. Rev. Int'1 Arb. 597, 4.

7 UNCITRAL Model Law on International Commercial Arbitration 24 ILM 1302 (1985).

8 Superior Tribunal of Justice. Conflict of Competence no. 139.519 - RJ (2015/00766352), Reporting Justice Nancy Andrighi, judged on 15 April 2015, published in the DJ (Court Reporter) of April 20, 2015.

9 According to the art. V(2) NYC, the recognition and enforcement of an arbitral award may be refused if the competent authority in the country where recognition and enforcement is sought finds that: (a) the subject matter of the difference is not capable of settlement by arbitration under the law of that country; or (b) the recognition or enforcement of the award is contrary to the public policy of that country. 
denied in Brazil if the STJ ascertains that: I- in accordance with Brazilian law, the subject matter of the dispute is not capable of settlement by arbitration; II-the decision is offensive to public policy ${ }^{10}$.

According to Article 1 of the BAA, persons capable of contracting may settle through arbitration disputes related to rights over which they may dispose ${ }^{11}$. Thus, the STJ may refuse enforcement of arbitral awards related to rights that are not disposable under Brazilian law. Given that the definition of disposable rights is not expressly stated in Brazilian law, it is necessary to define the parameters of what subjects can and cannot be settled by arbitration, especially oriented, in this study, to matters related to energy and natural resources.

The presence of arbitration clauses in the concession contracts for exploration and production of oil and gas in Brazil raises questions related to the disposability of the rights concerned. It is paramount to set benchmarks on arbitral tribunals' power to decide on these matters and to define to what extent arbitral awards may defy public policy, national sovereignty over natural resources and national courts' jurisdiction to render decisions in this regard. Otherwise, the randomness of judicial decisions, allowing or not the arbitration in each case, makes the arbitration clause ineffective. According to Kaplan:

The reality is that, as far as I know, few of the developing countries who have adopted the New York Convention have taken any steps to ensure that they have a judiciary capable of ensuring that the treaty obligations they have assumed are honoured in practice' Fortunately, some steps may be taken to attempt to improve this situation. Court familiarity with the NYC grows naturally with exposure, but seminars and training for the judiciary might help improve familiarity in the short term ${ }^{12}$.

In order to deepen this study, I analyze a recent case in the Brazilian oil and gas industry. The conflict arose from a decision made by the National Petroleum, Natural Gas and Biofuels Agency (ANP), contested by the concessionaire. The latter requested arbitration under the ICC, as stipulated in the arbitration clause (clause 31.4) of the concession

10 Article 39, BAA.

11 Article 1, BAA.

12 Neil Kaplan, Speech to the Franco-British Law Society in Paris in 2001 (19(2)Journal of International Arbitration 2002) 170 (as cited in Quentin Tannock:, 'Judging the Effectiveness of Arbitration through the Assessment of Compliance with and Enforcement of International Arbitration Awards' 21 Arbitration International (2005)76). 
agreement ${ }^{13}$. The ANP filed an action with a federal court in Rio de Janeiro (the Agency's headquarters venue) to stop the arbitration, claiming the subject matter was not arbitrable and had to be decided by national courts. The court ruled in favor of the ANP, sent a request to the ICC to stop the arbitration and stated its own jurisdiction to decide the dispute ${ }^{14}$.

Based on the described case (henceforth the "Lula case"), this study aims to examine the legal issues involved, especially those related to determination of jurisdiction and to arbitrability of matters concerning energy and natural resources, arguably connected to public policy grounds. The work analyzes how arbitral tribunals, national courts and the legal community have been treating the issues worldwide.

The second part presents briefly the Lula Case and how the Brazilian Judiciary considered the case. The third part address issues of general international commercial arbitration, such as jurisdiction and arbitrability, and it also discusses the consequences of considering a State act as a sovereign act, under the perspective of the international practice in the oil and gas industry and the transnational standards present in lex petrolea. It is important to remember that the judicial decision in the Lula case just considered the act ius imperium in order to fix the jurisdiction, by saying that, for its nature, the right was not disposable and dispute was not arbitrable ${ }^{15}$. The merits of the pleading, about if the act caused damage to investors and whether or not the damages have to be compensated has not been faced yet.

Thus, the fourth part of this article will only theoretically consider the concerns related to the consequences of sovereign acts, especially when they affect investors or private parties in the energy industry, according to international standards. The Lula case raises substantive issues that are often faced in international arbitrations worldwide. Then, the international approach is studied in broad terms, as guidance to future regulatory acts, national court decisions and future arbitrations related to oil and gas in Brazil.

\section{THE LULa CASE}

Petrobras, BG E\&P Brasil Ltda and Petrogal Brasil S.A, in a consortium, signed a concession agreement to explore and produce oil and gas in the area called Block BM-S-11, as a result of the 2nd

13 National Petroleum, Natural Gas and Biofuels Agency (ANP), 2 ${ }^{\text {nd }}$ Bidding Round Concession Agreement <http://www.brasilrounds.gov.br/round2/arquivos_r2/Edital/Edital_ en.pdf $>$ accessed 29 July 2015.

$141^{\text {st }}$ Federal Court of the Judiciary Section of Rio de Janeiro. Ordinary Action no. 000596681.2014.4.02.5101, Justice Mauro Souza Marques da Costa Braga, judged on 15 May 2015, published in the DJ (Court Reporter) of May 26, 2015.

15 Ibid. 
Brazilian Concessions Bidding Round in $2000{ }^{16}$.

After the implementation of the minimum work exploration program and carrying out the activities contained in the discovery evaluation plan, the consortium submitted to the National Petroleum, Natural Gas, and Biofuels Agency (ANP) two development plans for the establishment of two oil fields in contiguous areas. The proposal was rejected by the ANP's Board of Directors, which rejected the consortium's request to separate the field into two parts, arguing its uniqueness (the block is hereinafter called "Lula field") ${ }^{17}$.

Considering the failure of the Consortium to achieve the division of the Lula field into two oil fields, the Consortium started proceedings to submit the ANP's decision to arbitration, under the auspices of the ICC. The main arbitration claim was to replace the regulatory decision and to allow the establishment of two fields: Lula field and Cernambi field. The mediate claim, or the expectation by dividing the area into two oil fields, was to reduce the amount of the so-called Special Participation, a government take which was estimated by ANP at about thirty billion dollars for the Lula field ${ }^{18}$.

The ANP filed for an antiarbitration injunction in the Federal Justice System in Rio de Janeiro, arguing that the contents of the regulatory decision on the development plan could not be settled by arbitration since it is not a disposable right. The ANP argued that when there is a controversy over whether or not the right is disposable, only the judiciary can resolve it, thus preventing continuation of the arbitral proceeding ${ }^{19}$.

Hence, the ANP brought an action to suspend the arbitration. The two main issues to be solved in the judicial case were: i) whether the arbitral tribunal has jurisdiction to define its own jurisdiction, even to determine arbitrability, leaving to recalcitrant parties the option to file an annulment action; ii) if the subject of controversy brought to the notice of arbitration is disposable or not ${ }^{20}$.

About the first issue, related to who has jurisdiction to decide

16 Results of the $2^{\text {nd }}$ Bidding Round <http://www.anp.gov.br/brasil-rounds/round2/pdocs/ Pinicial/Presultados.htm > accessed 29 July 2015.

17 In the ANP Board Resolution no. 568/2011, Administrative Process No: 48610.002618/2011, Board Meeting No: 624, 22 July 2011 was decided: 'I) To reject the concessionaire's request to separate the Lula field into two parts, keeping it unique, which will be hereinafter "Lula field", covering the discovery made by well 1-BRSA-369A- RJS and surrounding areas, including the area of the 4-BRSA-711-RJS well; and

II) To determine that the operator send a single development plan of the Lula field, including the areas mentioned above, in a maximum period of 90 days from the date of this Board Resolution'<http://www.anp.gov.br/?id=2886> accessed 20 June 2015.

$181^{\text {st }}$ Federal Court of the Judiciary Section of Rio de Janeiro (n 14).

19 Ibid.

20 Ibid. 
on the jurisdiction, whether the arbitral tribunal or the national court, the judge held that the decision is to be given by a national court. The decision considered that if the parties, or at least one, already know in advance that there is a suspicion that the right at stake is not disposable, the judge has jurisdiction to examine the allegation ${ }^{21}$.

The Article 25 of Brazilian Arbitration Act (BBA) states that 'if during the course of the proceedings, a dispute arises regarding rights that are not disposable, and once convinced that the final decision may depend thereon, the sole arbitrator or the arbitral tribunal may refer the parties to the State Court having jurisdiction, ordering a stay of the arbitral proceedings'. The judge considered that Article 25 of the BAA is directed towards the arbitral tribunal, not preventing the national courts from assessing the adequacy of the arbitration regarding its legal limits, which in this case involves the provisions of art. 1 of the BAA, that states that only disposable rights can be decided by arbitration. The court held that the legality control of the limits of the arbitration agreement was not to be reviewed solely by the arbitral tribunal and if there were doubts concerning the arbitrability of the dispute, it would be a waste of time to wait for the arbitral tribunal's decision first in order to file suit to annul it after that ${ }^{22}$.

On the second question, if the right is disposable or not, the court established that the discussion on the regulatory decision that stated that the block contained in the concession area is to be divided into two fields, is an insurgency against the ANP's regulatory decision. According to the judge, the complaint is a concessionaire's attempt to discuss the imperativeness of administrative acts in arbitration, which is not possible ${ }^{23}$.

These two issues that arose in the Lula case, on the jurisdiction to decide on arbitrability and on the arbitrability of disputes related to State acts, will be broadly considered next. Due to the absence of consistent jurisprudence from the courts in this regard, this discussion is important to enhance the arbitration institute in Brazil.

\section{GENERAL ISSUES OF INTERNATIONAL COMMERCIAL ARBITRATION RELATED TO THE DISPUTE}

\subsection{Arbitrability}

Arbitrability involves the question of what subjects can be submitted to arbitration, placing limits on what may be adjudicated by

21 Ibid.

22 National Petroleum, Natural Gas and Biofuels Agency (n 13).

$231^{\text {st }}$ Federal Court of the Judiciary Section of Rio de Janeiro (n 14). 
an arbitral tribunal ${ }^{24}$. According to Lauren Brazier, arbitrability has been concerned with particular 'subject-matters that cannot be decided by arbitration, even if the parties have otherwise validly agreed to arbitrate such matters', because the matters inherently involve some sort of public interest. Instead, these subject-matters belong 'exclusively to the domain of the courts' as protectors of the public interest involved' 25 .

Bernard Hanotiau argues that arbitrability can be challenged in two different ways. The first one is based on the quality of one of the parties, when this party is a State, a public collectivity or entity or a public body, and is named "subjective arbitrability" or "arbitrability ratione personae". The second is based on the subject matter of the dispute, which the applicable national law has removed from the domain of arbitrable matters, and is named "objective arbitrability" or "arbitrability ratione materiae" "26.

\subsubsection{Subjective arbitrability}

Hanotiau observes that although initially the issue of subjective arbitrability was decided in accordance with the law determined by conflict of law rules, namely the law governing capacity, this method has been progressively abandoned and today the issue is generally determined by the application of a substantive rule of international law ${ }^{27}$. For the author, there seems to be general agreement that the subjective arbitrability of international disputes to which a State, a public entity or a public body is party is, despite the contents of the domestic law of the State or entity concerned, a principle of international public policy of the law of international arbitration ${ }^{28}$.

Likewise, Julian D. M. Lew says that the issue of subjective arbitrability is governed by a substantive rule of international arbitration and not by the law of the state party. This rule requires state parties to honour the arbitration agreement, precluding them from relying on national restrictions to avoid the effects of arbitration agreements. This is derived from international arbitration practice and provisions in various laws and conventions ${ }^{29}$. In particular, the European Convention expressly provides for the subjective arbitrability of state parties and

24 Julian DM Lew, Loukas A Mistelis and Stefan M Kröll, Comparative International Commercial Arbitration (Kluwer Law International 2003) 187.

25 Lauren Brazier, 'The Arbitrability of Investor-State Taxation Disputes in International Commercial Arbitration' 32 Kluwer Law Online 1, 20.

26 Bernard Hanotiau, 'The Law Applicable to Arbitrability' (2014) 26 Singapore Academy of Law Journal 875.

27 Ibid 876.

28 Ibid 877.

29 Lew, Mistelis and Kröll (n 24) 738. 
the ICSID Convention relies on the premise that a state party that has agreed to arbitrate is bound by its commitment ${ }^{30}$. Likewise, under Article 177(2) PIL $^{31}$, a State, a state-held enterprise or a state-owned organisation, as a party to an arbitration agreement, can neither rely on its own law for the purpose of challenging its own capacity nor can it invoke its own laws to contest the arbitrability of the dispute at hand ${ }^{32}$.

Since the BAA was enacted in 1996, it had no express restriction for State participation in arbitration. In fact, the Brazilian Concessions' $\mathrm{Law}^{33}$ and the Public-Private Partnerships $\mathrm{Law}^{34}$ already provided for State participation, and the STJ had recognized the validity of this provision in its decisions ${ }^{35}$. Recently, Law 13,129/2015 amended the BAA to include an express provision authorizing the direct and indirect public administration to resolve disputes related to disposable pecuniary rights by arbitration ${ }^{36}$.

Moreover, the Brazilian Law 9,478/97 (hereinafter named 'Brazilian Petroleum Law') states that the solution of disputes involving oil and gas agreements can occur by international arbitration ${ }^{37}$. Thus, there is no impediment to a public-sector entity being a party to arbitration. In the Lula case, the ANP, as a state entity, has not argued either about contractual or statutory provisions against arbitration for administrative contracts, but about the matter of objective arbitrability.

\subsubsection{Objective arbitrability}

Arbitrability in essence is a matter of national public policy, which differs from one country to another. According to Patrick Baron and Stefan Liniger, judges of different countries will look at the question of whether a given dispute is arbitrable from different angles and arbitrators will take a yet different approach ${ }^{38}$. Besides that, State judges tend to decide

\section{Ibid.}

31 Switzerland's Federal Code on Private International Law (CPIL)1 of December 18, 19872. 32 Patrick M Baron and Stefan Liniger, 'A Second Look at Arbitrability: Approaches to Arbitration in the United States, Switzerland and Germany' (2003) 19 Arbitration International 27.

33 Brazilian Law 8,987/ 1995.

34 Brazilian Law 11,079/2004.

35 Camila Tomimatsu and Mariana Cattel, 'The Recent Amendments to the Brazilian Arbitration Act - One Step Back, Two Steps Forward?' < http://kluwerarbitrationblog.com/ blog/2015/06/30/the-recent-amendments-to-the-brazilian-arbitration-act-one-step-back-twosteps-forward/> accessed 14 July 2015.

36 Article 1, § 1, Brazilian Law 13,129/ 2015.

37 Article 43, Brazilian Law 9,478/97 states that 'The concession contract shall duly reflect the conditions of the tender announcement and the winning proposal shall have the following essential clauses: $\mathrm{X}$ - the rules for the solution of controversies relating the contract and its performance, including by international conciliation and arbitration'.

38 Baron and Liniger (n 32) 27. 
according their national laws and interests and arbitrators seek a balance between the interests of the legal systems concerned in the dispute and the reasonable expectations of the parties of the proceeding ${ }^{39}$.

The classic examples of subjects considered inarbitrable include certain issues arising in criminal, domestic relations, bankruptcy, real property and governmental sanctions matters ${ }^{40}$. It has been argued that certain types of investment contracts are not arbitrable since they involve aspects of sovereignty over natural resources or other issues of ius cogens, so that arbitrators are not authorized to pronounce on the validity of sovereign actions ${ }^{41}$. This work will analyse the objective arbitrability, especially related to the public policy objection presented by the ANP to deny the arbitrability of a dispute related to natural resources.

\subsection{Law applicable to determine arbitrability}

The practice of international arbitration proves that the issue of which law governs arbitrability is not an easy one and that the answer may depend upon the tribunal or court before which it arises. The solution to the issue can vary depending on whether it is decided by an arbitral tribunal, a state court to which one of the parties has concurrently submitted the dispute in the course of a setting-aside or enforcement proceeding ${ }^{42}$.

Brazier argues that a determination of arbitrability may arise at several stages in the arbitral process, and in several different forums. These include (a) before the tribunal at the beginning of the proceeding; (b) before a national court, either as a preliminary matter to be determined before the arbitration can go ahead, or as a question of whether the award should be set aside; and (c) before the court of enforcement ${ }^{43}$. At each stage, the question arises is what law governs arbitrability.

3.2.1. Different forums and stages where the arbitrability issue can arise

\subsubsection{In national courts as a preliminary matter or a question of whether the award should be set aside}

Suppose one of the parties has commenced the arbitration in compliance with an arbitration clause and the other party considers that the

39 Ibid 28.

40 Gary Born, International Commercial Arbitration (Second edition, Kluwer Law International 2014) 949 .

41 Lew, Mistelis and Kröll (n 24) 219.

42 Hanotiau (n 26) 878.

43 Brazier (n 25) 3. 
dispute is not arbitrable and applies to a national court to stop the arbitration. How is the national court going to decide this issue of arbitrability?

According to Hanotiau, it will apply its own national law, and this is the appropriate view even if some authors and various courts hold that the law applicable to the validity of the arbitration clause should determine arbitrability ${ }^{44}$.

Stravos Brekoulakis also believes that the best answer is the lex fori and that the provision of art. V(2)(a) of the NYC, although referring to the enforcement stage, has a wider effect than the scope of application, endorsing the lex fori even when the issue of arbitrability arises before a national court at other stages than enforcement, especially when national courts review arbitrability at the stage of challenge ${ }^{45}$. According to the author, most national provisions on challenge mirror the NYC art. V, and thus, make express reference to lex for ${ }^{46}$.

According to the tendency, the issue of arbitrability should be decided without reference to a domestic law, through the application of an international rule of substantive law ${ }^{47}$. For example, in the United States District Court decision of 29 March 1991, the Court emphasized that that "courts of NYC signatory countries in which an agreement to arbitrate is sought to be enforced could not decline enforcement of such agreements on the basis of parochial views of their desirability or in a manner that would diminish the mutually binding nature of the agreements." 48 According to this view, the principle of favor arbitrandum should prevail in case of doubt ${ }^{49}$. Nevertheless, the choice of transnational public policy is not its most conventional one, since the function of public policy is to exclude agreements, rules or decisions that oppose certain fundamental values or interests ${ }^{50}$.

If national statutes provide for the possibility of setting aside an award if it is contrary to public policy or if the dispute is not capable of settlement by arbitration, the national court concerned will normally apply its own national law to decide the issue ${ }^{51}$. The UNCITRAL Model Law also provides ${ }^{52}$ that an arbitral award may be set aside by the court

44 Hanotiau (n 26) 883.

45 Stavros Brekoulakis, 'Law Applicable to Arbitrability: Revisiting the Revisited Lex Fori' 2 $<$ http://papers.ssrn.com/sol3/papers.cfm?abstract_id=1414323> accessed 15 July 2015. 46 Ibid.

47 Bernard Hanotiau, 'La Loi Applicable a L'Arbitrabilite Du Litige' [1998] Int'1 Bus. LJ 755, 402.

48 Ibid.

49 Ibid.

50 Brazier (n 25) 7.

51 Hanotiau (n 26) 883.

52 Article 34(2)(b)(i) (2), UNCITRAL Model Law. 
mentioned in Article $6^{53}$ only if the court finds that the subject-matter of the dispute is not capable of settlement by arbitration under the law of this State ${ }^{54}$.

Finally, even applying national law, national courts cannot use public policy arguments broadly, in order to restrain international arbitration or set aside arbitral awards ${ }^{55}$. In Hanotiau's words:

\begin{abstract}
[...] it is certain that the field of arbitrable matters is considerably expanding. On the one hand, the role that public policy plays in the field of arbitrability has been considerably narrowed. On the other hand, material rules specific to international arbitration are emerging in national legal systems, either in the case law, or in newly adopted statutes ${ }^{56}$.
\end{abstract}

\title{
3.2.1.2. In the enforcement stage
}

When raised at the time of enforcement, the applicable law is the one of the place where it will have to be enforced. The enforcement judge will normally apply art. V(2) of the NYC. Despite the waning role of public policy, the prominence of lex fori as the most relevant law to determine arbitrability remains unquestionable, especially when the issue arises before a national court at the enforcement stage, when the express mandate of the NYC leaves very little space, if any, for a different view ${ }^{57}$.

Reference is often made to the decision of the US Second Circuit Court of Appeals in Parsons and Whittemore Overseas Co Inc $v$ Socit-Gn\&ale de L'Industrie du Papier (Rakta) ${ }^{58}$, in which the Court of Appeals decided that only a violation of the forum State's most basic notions of morality and justice would justify refusal to enforce an arbitral award ${ }^{59}$. The BAA, mirroring the NYC, expressly states that national courts shall deny recognition or enforcement if, in accordance with Brazilian law, the subject matter in dispute is not capable of settlement by arbitration ${ }^{60}$.

53 Article 6, UNCITRAL Model Law.

54 Hanotiau (n 47) 402.

55 Ibid 403.

56 Ibid.

57 Brekoulakis (n 45) 2.

58 Parsons \& Whittemore Overseas Co. Inc. v Soceite Generale de l'Industrie du Papier (RAKTA) 508 F.2d 969 (2nd Cir. 1974).

59 Locknie Hsu, 'Public Policy Considerations in International Arbitration: Costs and Other Issues A View from Singapore’ (2009) 26 Journal of International Arbitration 101, 884.

60 Article 39, BAA. 


\subsubsection{By the arbitral tribunal}

If the question arises before the tribunal at the beginning of the proceeding, which law should the arbitrators apply? Should they consider the fact that the award would subsequently have to be enforced in another country?

Hanoutiau says the arbitral tribunal will decide it by application of the law that governs the arbitration agreement, ie, the autonomously chosen law $^{61}$. According to him, this is the solution expressly provided by art. II(1) and art. V(1)(a) of the NYC. However, in most cases parties have not provided any express indication in this respect ${ }^{62}$.

Lauren Brazier makes a thorough analysis of the most appropriate law to determine arbitrability. First, she considers the law governing the arbitration agreement, but argues that this approach takes the autonomy justification for using the law governing the arbitration agreement to an extreme, since it is one thing to respect parties' choices as to the applicable law, and quite another for that choice to be allowed to undermine the basis of the doctrine of arbitrability. Thus, the law governing the arbitration agreement would be an unusual starting point for determining arbitrability in the investor-State context $t^{63}$.

Lauren Brazier also wonders if the lex arbitri or the law of the seat of arbitration should govern arbitrability, but finds that it is unlikely to have a close connection with the underlying commercial agreement, since the choice of the seat is usually determined by factors such as convenience or neutrality, and not by the law of the specific forum chosen ${ }^{64}$.

Finally, Brazier argues that the most appropriate view is that arbitrability should be determined by a transnational public policy, defined as the set of principles, not pertaining to the law of a particular State and reliant on consensus between States. The transnational approach is appropriate because national public policy rules applying to arbitrability in international arbitration are increasingly less restrictive than those which apply in domestic arbitrations and because transnational public policy is not tied to the law that the parties have selected, separating the law governing arbitrability from issues involving the choice of the parties ${ }^{65}$.

Nevertheless, this view may lead to unwanted practical consequences in cases where the law of the place of arbitration contains a narrower concept of arbitrability than the "genuinely international public

61 Hanotiau (n 26) 879.

62 Ibid.

63 Brazier (n 25) 5.

64 Ibid 6.

65 Ibid 8. 
policy" ${ }^{\prime 66}$. In these cases, necessary measures of support from the courts of the place of arbitration may not be available, the award may be open to challenge and the unsuccessful party may later attack a genuine matter of international public policy during the enforcement stage ${ }^{67}$.

In most cases, tribunals determine the arbitrability of a dispute based on provisions of the place of arbitration ${ }^{68}$. Although arbitral tribunals have no duty to apply lex fori, it is accepted as the safest option for a tribunal, in order to avoid a potential challenge of the award in the national court of the place of arbitration, which in turn would be bound to apply lex fori ${ }^{69}$.

\subsection{Jurisdiction}

The Kompetenz-Kompetenz principle refers to the allocation of authority between an arbitral tribunal and a national court over the interpretation and enforceability of arbitration agreements. The principle, developed in Germany, authorizes an arbitral tribunal to determine its own jurisdiction without requesting a judicial decision ${ }^{70}$.

Natasha Wyss ${ }^{71}$ says that the right of an arbitral tribunal to rule on its own jurisdiction is generally accepted throughout the world. However, the doctrine has developed into a legal term of art in most countries, such as "Kompetenz-Kompetenz" in Germany; "competence de la competence" in France, and "competence of competence" in England, and legal implications of the doctrine change with its translation. Likewise, William Park says that in commercial arbitration, it depends largely on national law and institutional rules, making it more accurate to speak of Kompetenz-Kompetenz doctrines in the plural:

To illustrate, in the United States courts mayentertain applications for jurisdictional declarations at any time, and may order full examination of the parties' intent to arbitrate. If German courts are asked to hear a matter which one side asserts must be arbitrated, they decide immediately on the validity and scope of the arbitration agreement. In

66 Lew, Mistelis and Kröll (n 24) 197.

67 Ibid.

68 Fincantieri- Cantieri Navali Italiiani and Oto Melara v. Mvand arbitration tribunal v, (1995) XX YBCA 766 (with regard to claims arising out of illegal activities)

69 Lew, Mistelis and Kröll (n 24) 197.

70 Adrianna Dulic, 'First Options of Chicago, Inc. v. Kaplan and the Kompetenz-Kompetenz Principle’ (2002) 2 Pepp. Disp. Resol. LJ 77, 2.

71 Natasha Wyss, 'First Options of Chicago, Inc. v. Kaplan: A Perilous Approach to KompetenzKompetenz' (1997) 72 Tul. L. Rev. 351, 352. 
neighbouring France, such challenges normally wait until an award has been made. In England, litigants have a right to declaratory decisions on arbitral authority, but only if they take no part in the arbitration ${ }^{72}$.

About the question of who has jurisdiction to determine arbitrability, the United States has a liberal approach. According to Kenneth R Pierce, the court shall see whether the parties objectively revealed an intent to submit the arbitrability question itself to arbitration, but admits it is hard to say, since parties usually incorporate a standard broad clause into their contracts without thinking about it $^{73}$.

The timing of judicial review is also an issue. On one hand, going to court at the beginning of the proceeding can save expense for a respondent improperly joined to the arbitration. On the other hand, judicial resources may be preserved by delaying review until the end of the case, by which time the parties might have settled ${ }^{74}$. The French model delays court consideration of jurisdictional matters until the award review stage, which can reduce the chance of dilatory tactics, since a bad-faith respondent will be less able to add the cost of a court challenge while the arbitration is pending ${ }^{75}$.

However, the high costs of arbitration and the principle of legal certainty have even made the courts of Germany, the birthplace of Kompetenz-Kompetenz, recognize the possibility of judicial review of the arbitral jurisdiction in the pre-arbitration phase ${ }^{76}$. Under section 1032(2) of the German ZPO, a German court may only decide the arbitrators' jurisdiction if requested to do so before the arbitral tribunal is constituted ${ }^{77}$. Brekoulakis observes that section 1032 now regulates the allocation of tasks between national courts and arbitral tribunals and it is no longer possible for the parties to provide that an arbitral tribunal will have the final and binding say for German courts in relation to the

72 William W Park, ‘Arbitral Jurisdiction in the United States: Who Decides What?' (2008) 11 International arbitration law review 33, 38.

73 Kenneth R Pierce, 'Down the Rabbit Hole: Who Decides What's Arbitrable?' (2004) 21 Journal of International Arbitration 289, 292.

74 William W. Park, The Arbitrator's Jurisdiction to Determine Jurisdiction' (2006) ICCA Congress, Montreal.13 ICCA Congress Series $55<\mathrm{http}$ //www.arbitrationicca.org/ media/0/12409326410520/jurisdiction_to_determine_jurisdiction_w_w_park.pdf $>$ accessed 29 July, 2015

75 Ibid.

76 Stavros Brekoulakis, 'The Negative Effect of Competence-Competence: The Verdict Has to Be Negative' [2009] Austrian arbitration yearbook 238, 245.

77 John J Barcelo III, 'Who Decides the Arbitrator's Jurisdiction-Separability and CompetenceCompetence in Transnational Perspective' (2003) 36 Vand. J. Transnat'l L. 1115, 1131. 
determination of the validity of an arbitration agreement. In particular, a state court may assume jurisdiction over a claim on the jurisdiction of a tribunal, but only at a stage prior to the constitution of the arbitral tribunal, since after that, an arbitral tribunal acquires the exclusive jurisdiction to decide on the validity of the arbitration agreement ${ }^{78}$.

According to Brekoulakis, the principle of competencecompetence asserts that an arbitral tribunal has the jurisdiction to address a claim which undermines the premise of its own authority, providing arbitrators with the power to begin with the question ${ }^{79}$. The competence-competence principle arguably generates two effects. The positive effect means that the arbitral tribunal has jurisdiction to decide on its own jurisdiction ${ }^{80}$ and the negative effect attributes exclusive jurisdiction to arbitral tribunals to examine the validity of an arbitration agreement. National courts have to refrain from reviewing the jurisdiction of a tribunal until the stage of challenge or enforcement of an arbitral award ${ }^{81}$.

Brekoulakis says that while the principle of competencecompetence started as a legal convention aiming to strengthen the jurisdiction of arbitral tribunals, it has now developed into a legal paradox $^{82}$. For the author, while the positive effect of the competencecompetence principle is essential to maintain the autonomy of arbitration, the negative effect undermines legitimacy of arbitration proceedings, leading to an overly expensive pro-arbitration policy that encourages an anti-arbitration reaction ${ }^{83}$.

According to the competence-competence principle, an arbitral tribunal has authority to decide upon its jurisdiction and, in making such a decision, it will review the respective arbitration agreement, observing general legal principles that affects its jurisdiction. This decision will include an assessment as to whether the dispute is arbitrable, but the determination is not necessarily fina ${ }^{84}$. According to Patrick M. Baron and Stefan Liniger, the arbitral tribunal's determination might be subject to judicial review and in a demand to set aside an award or at the recognition and enforcement stage, a court may take a second look at the arbitrability of a particular matter ${ }^{85}$.

The First Options of Chicago v. Kaplan ${ }^{86}$ case is often mentioned

78 Brekoulakis (n 76) 245.

79 Ibid 238.

80 Ibid 251.

81 Ibid 239.

82 Ibid 238.

83 Ibid 245.

84 Baron and Liniger (n 32) 27.

85 Ibid.

86 U.S. Supreme Court, First Options of Chicago, Inc. v. Kaplan (94-560), 514 U.S. 938 (1995). 
on the matter of application of Kompetenz-Kompetenz. In this case, the Court of Appeals disagreed with the arbitral tribunal on the matter of its jurisdiction and determined that the Kaplans were not bound to arbitrate, reversing the lower court confirmation of the award. A unanimous Supreme Court affirmed the Court of Appeals decision, stating that the arbitrability was a question for the courts to decide ${ }^{87}$.

Another theory connected with this approach is called the "second look doctrine", which although not holding the arbitration agreement to be invalid, preserves the subsequent possibility to annul or refuse recognition and enforcement of arbitral awards that are contrary to the lex fori ${ }^{88}$. In the emblematic Dallah case ${ }^{89}$ the UK Supreme Court decided to deny recognition of the arbitral award, following what it termed an independent investigation of whether the tribunal had jurisdiction. The Court revisited the arbitral tribunal's decision on jurisdiction and considered it was not bound or restricted by the tribunal's conclusions ${ }^{90}$.

According to Gary Bornand, the regrettable course of the Dallah case and the conflict between the French and English decisions are pathological, since the most fundamental objectives of the NYC were violated, including ensuring uniform treatment of arbitral awards and facilitating the effective enforcement of such awards in the Convention's Contracting States ${ }^{91}$.

Brazilian courts can analyze the question of arbitrability even during an ongoing arbitration proceeding if the question is raised by an arbitrator, as expressly stated in art. 25 of the BAA. The answer is not so obvious if the jurisdiction issue is brought to national courts during the arbitral proceeding by the party that believes the dispute is not arbitrable. As mentioned before, in the first-instance decision of the Lula case ${ }^{92}$, the judge held that the judiciary has the final word on jurisdiction when the question is brought to a national court by one of the parties, even during the arbitral proceeding. The judge decided that the arbitration shall be suspended until the national court decides on the arbitrability issue.

87 William W Park, 'The Arbitrability Dicta in First Options v. Kaplan: What Sort of KompetenzKompetenz Has Crossed the Atlantic?' (1996) 12 Arbitration International 137, 140.

88 Alexander J Belohlavek, 'The Law Applicable to the Arbitration Agreement and the Arbitrability of a Dispute' [2013] Yearbook of International Arbitration, M. Roth and M. Giestlinger (eds.), Intersentia/DIKE/NWV, Antwerpen-Zurich-Vienna-Graz 27, 9.

89 Dallah Real Estate and Tourism Holding Company v The Ministry of Religious Affairs, Government of Pakistan [2010] UKSC 46.

90 Gary Born and others, 'Dallah and the New York Convention' $<$ http://kluwerarbitrationblog. com/blog/2011/04/07/dallah-and-the-new-york-convention/> accessed 14 July 2015.

91 Ibid.

$921^{\text {st }}$ Federal Court of the Judiciary Section of Rio de Janeiro (n 14). 


\subsection{Arbitrability and Public policy}

In many countries, arbitration statutes deal only with domestic arbitration, and do not cover all aspects of arbitration ${ }^{93}$. Most recent statutes do not regulate questions of arbitrability and problems that affect foreign state capacity to arbitrate, including sovereign immunity from suit and from execution of the award ${ }^{94}$.

Although NYC sets forth two bases for non-recognition, the public policy of the enforcement forum (in Article $\mathrm{V}(2)(\mathrm{b})$ ) and the nonarbitrability rules of the enforcement forum (in Article V(2)(a)), in many respects, the doctrine of public policy parallels the nonarbitrability doctrine $^{95}$. In both, even if parties agree to arbitrate their disputes, their agreements to arbitrate may be unenforceable in some jurisdictions as applied to limited categories of issues. The rationale is the same and bases on the premise that there are unacceptable conflicts between the award or arbitration agreement and basic public policies and legal norms of a particular state, which that state is permitted, exceptionally, to invoke to justify non-recognition of an otherwise valid award or agreemen ${ }^{96}$. In Lula case, for instance, public policy grounds were used to support that the right is not disposable because of the public interest involved and, thus, the dispute could not be settled by arbitration according to BAA.

Despite that the limits of arbitrability usually concern public policy grounds, few laws expressly determine what public policy is. The interpretation will depend on the context of each country. In arbitration-friendly countries, not all public policy rules can impair arbitration $^{97}$. Despite a general bias in favour of enforcement ${ }^{98}$, there are substantive and procedural limits beyond which arbitrators may not go. Enforcement may be refused if an award purports to decide allegations involving the enforcing country's fundamental economic policies or if the arbitration proceeding was procedurally deficient in some fundamental aspect ${ }^{99}$.

Hsu says that when international jurists and experts were formulating Article 34 of the Model Law, there was a great deal of discussion as to its scope, but the final interpretation was narrow:

93 Henry P DeVries, 'International Commercial Arbitration: A Contractual Substitute for National Courts' (1982) 57 Tul. L. Rev. 42, 52,

94 Ibid.

95 Born (n 40) 949.

96 Ibid.

97 Lew, Mistelis and Kröll (n 24) 200.

98 Troy L Harris, "The "Public Policy" Exception to Enforcement of International Arbitration Awards Under the New York Convention-With Particular Reference to Construction Disputes' (2007) 24 Journal of International Arbitration 9, 1.

99 Ibid. 
In discussing the term 'public policy', it was understood that it was not equivalent to the political stance or international policies of a State but comprised the fundamental notions and principles of justice. It was understood that the term 'public policy', which was used in the 1958 New York Convention and many other treaties, covered fundamental principles of law and justice in substantive as well as procedural respects. Thus, instances such as corruption, bribery or fraud and similar serious cases would constitute a ground for setting aside ${ }^{100}$.

The differences between the various approaches are diminishing with the gradual enlargement of the scope of arbitration in most countries. There are areas where the issue of arbitrability traditionally arises such as antitrust, securities transactions, insolvency, intellectual property rights, illegality and fraud, bribery and corruption, and investments in natural resources ${ }^{101}$.

A consensus also seems to exist regarding the existence of two approaches to public policy, depending on whether the arbitration is classified as domestic or international ${ }^{102}$. Even some claims that are not arbitrable in domestic arbitration, based on public policy grounds, have been found to be arbitrable, including securities and antitrust claims ${ }^{103}$. Troy L. Harris says that "while a public policy argument is sometimes dismissed as the last resort of the desperate, public policy is also 'a variable notion' that is 'open-textured and flexible' 104 .

In the United States, courts have set forth limitations to the parties' freedom to arbitrate disputes in specific areas of law that were traditionally considered to be within the exclusive domain of state and federal courts, in particular those involving strong public interest ${ }^{105}$. Over the last couple of decades, however, U.S. courts have increasingly taken an arbitration-friendly approach and limited public policy considerations to fewer types of controversies ${ }^{106}$.

This approach was influenced primarily by the decision in the

$100 \mathrm{Hsu}$ (n 59) 109.

101 Lew, Mistelis and Kröll (n 24) 201.

102 Leonardo VP de Oliveira and Isabel Miranda, 'International Public Policy and Recognition and Enforcement of Foreign Arbitral Awards in Brazil' 30 Journal of International Arbitration $201349,51$.

103 Harris (n 98) 11.

104 Ibid.

105 Baron and Liniger (n 32) 28.

106 Ibid 29. 
Mitsubishi Motors Corp. v. Soler Chrysler-Plymouth Inc case ${ }^{107}$, which is often referred to in connection with the theory that a dispute which is not arbitrable under national law can, nonetheless, be submitted to international arbitration. Accordingly, an arbitration agreement considered invalid under national law can still be a valid basis for the jurisdiction of arbitrators in international arbitration ${ }^{108}$. In Mitsubishi vs Soler ${ }^{109}$, the U.S. Supreme Court held that an automobile dealer's claim under the U.S. antitrust law could be decided in a Japanese arbitration proceeding, by being sensitive to the need for predictability in the resolution of disputes, which requires enforcement of the parties' agreement, even assuming that it would not happen in a domestic context $\mathrm{t}^{110}$.

International public policy is no longer the prerogative of arbitral tribunals; courts have started to adhere to it, especially in jurisdictions where arbitration is a traditional method of dispute resolution. In emerging countries like Brazil, the question of whether the international approach will be adopted remains to be answered ${ }^{111}$.

\subsubsection{Public policy in Brazil}

The reason for limiting arbitrability consists primarily of the desire to protect public policy of countries, which concerns in protecting the public interest and the weaker party in the proceeding ${ }^{112}$. National public policy is composed of the country's internal and external public policy. The internal policy comprises national policies recognized in customary law and legislation promulgated to regulate certain situations, which cannot be avoided or by-passed by the parties ${ }^{113}$. The external policy is part of the country's public policy applied to its external relationships, also called international public policy ${ }^{114}$. The expression "international public policy" (or in French, "ordre public international") also concerns the concept of public policy as applied in private international law, as a barrier to the application of a foreign statute by a state court on its rulings and on recognition of foreign arbitral awards ${ }^{115}$.

Before the enactment of the BAA, Article 17 of the Introductory Act to the Rules of Brazilian Law ${ }^{116}$ was the general rule that applied

107 U.S. Supreme Court, Mitsubishi v. Soler Chrysler-Plymouth, 473 U.S. 614 (1985)

108 Belohlavek (n 88) 9.

109 Ibid (n 104)

110 Harris (n 98) 13.

111 Oliveira and Miranda (n 102) 55.

112 Belohlavek (n 88) 10.

113 Oliveira and Miranda (n 102) 51.

114 Ibid.

115 Ibid 52.

116 Brazilian Decree-Law 4,657/ 1942. 
to the recognition of all foreign judgments, including foreign arbitral awards, by establishing that 'the laws, acts and judgments of another country and any declarations of will, shall not have effect in Brazil when they offend national sovereignty, public policy or good conduct' ${ }^{117}$.

The BAA does not significantly alter Brazil's practical limitations on arbitrability, which can serve as argument for a reluctant government to refuse arbitration of investment disputes ${ }^{118}$. The BAA limits the subject matter of arbitration to pecuniary rights of which the parties can freely dispose. This provision leaves open the possibility to frustrate an investment agreement because, under Brazilian law, neither the investor nor the government can "freely dispose" of the rights at issue ${ }^{119}$.

Brazilian courts have traditionally permitted themselves flexibility in interpreting the public policy defence to arbitration, raising concerns that a foreign investor might have difficulties to compel a Brazil state entity to arbitrate pursuant to an investment contract ${ }^{120}$. Actually, some commentators have already opined that issues of "public rights" and "State sovereignty", both crucial to investment disputes, are outside the domain of arbitrability under Brazilian law ${ }^{121}$.

Brazil has been hesitant to provide broad-based consent to arbitration of international investment disputes through domestic law or treaty ${ }^{122}$. Nowadays, investors can still obtain some protection by including arbitration provisions in their concession or investment agreements with the Brazilian government ${ }^{123}$. Therefore, investment arbitration agreements and awards involving the Brazilian government remain firmly based on the commercial arbitration regime ${ }^{124}$.

Where arbitration is conducted under the ICSID Rules, all Member States are obliged to automatically treat awards as local judgments, without any defence against enforcement, including public policy grounds ${ }^{125}$. Thus, in many international disputes, arbitration is not just a preferable way to obtain compensation; it is the only viable means of doing so $^{126}$.

Pedro Martini stresses that a fundamental distinction between arbitration against the State in Brazil and investment-treaty-arbitrations

117 Belohlavek (n 88) 55.

118 Noah D Rubins, 'Investment Arbitration in Brazil' (2003) 4 J. World Investment 1071, 1086.

119 Ibid.

120 Ibid.

121 Ibid.

122 Rubins (n 118).

123 Ibid 1072.

124 Rubins (n 118).

125 Ibid 1076.

126 Ibid. 
is that, while in arbitration against the Brazilian public administration the objective arbitrability refers to the nature of the claim, ie, if it relates to disposable rights, regardless of the context of such claim, in investment-treaty arbitration it is quite the opposite. It is not the nature of the claim itself that determines its capacity to be submitted to arbitration, but the context of the claim and of the activity of the investor in the host state, if there is an investment or not ${ }^{127}$.

The main reasons for Brazil's refusal to sign the ICSID Convention of 1965 were primarily directed at its investor-state arbitration mechanism, which Brazil's delegate believed contradicted the practice of direct state-to-state arbitration to resolve disputes involving treatment of their respective nationals. Brazil's delegate also suggested that investor-state arbitration violated constitutional principles of the Brazilian legal system, such as the principle that the judiciary holds a monopoly on justice. The final criticism was that it favoured foreign investors to the detriment of domestic investors ${ }^{128}$.

More than 50 years later, most Latin America countries have ratified the ICSID and Brazil's own approach to international commercial arbitration has evolved considerably ${ }^{129}$. Brazil has a modern and effective Arbitration Act, a more proarbitration approach by courts and the old view of unconstitutionality was remedied by Brazilian Federal Supreme Court ${ }^{130}$. Thus, most of the old criticisms are no longer tenable.

It is too early to say whether the BAA will satisfactorily compel enforcement of investment arbitration awards against the Brazilian government ${ }^{131}$. If Brazil's courts choose to apply the policy-based exceptions to enforcement broadly, investment arbitration effectiveness is likely to fail ${ }^{132}$.

\subsubsection{Sovereignty over natural resources}

Even a cursory look at the relationship between foreign investors and host States during the twentieth century exposes the uncertainties of this interdependence. The first half of that century saw the creation and then rapid growth of the international energy industry and many governments granted generous concessions to multinational oil corporations, with the title to the oil conveyed to the companies

127 Daniel de Andrade Levy, Ana Gerdau de Borja and Adriana Pucci (eds), Investment Protection in Brazil (Kluwer Law International 2014) 41.

128 Jean Kalicki and Suzana Medeiros, 'Investment Arbitration in Brazil' (2008) 24 Arbitration International 423, 431.

129 Ibid 433.

130 Brazilian Federal Supreme Court (n 3).

131 Rubins (n 118) 1087.

132 Ibid 1088. 
under long-term concessions or leases, with low royalties payable to the government ${ }^{133}$.

Unsurprisingly, developing nations soon changed this course. Nationalization of the oil industry, termination of those same concession or lease agreements and expropriation of the assets of foreign companies prevailed in the second half of the twentieth century ${ }^{134}$. On December 21, 1952, the United Nations General Assembly issued Resolution 626 (VII), providing for the right of peoples to exploit their natural resources as part of their sovereignty. It was the first General Assembly text to use the notion of 'permanent sovereignty over natural resources' 135 .

On December 14, 1962, the General Assembly adopted Resolution 1803 (XVII), stating that ' 1 . The right of peoples and nations to permanent sovereignty over their natural wealth and resources must be exercised in the interest of their national development and of the wellbeing of the people of the State concerned'136. The consequences of this statement increased intervention of governments, both of developed and developing countries, especially during the 1960s and 1970s $\mathrm{s}^{137}$. However, the same Resolution also provided that nationalization measures should only be implemented for public purposes, security or national interest and that the investor should receive "appropriate compensation" in compliance with domestic and international law ${ }^{138}$.

In the Resolution 3281 (XXIX), dated 26 July 1974, the General Assembly adopted the Charter of Economic Rights and Duties of States. This text enhanced that the right to nationalize foreign-owned property but required appropriate compensation, and admitted that if compensation was not paid, the State's international obligation would not respect good faith ${ }^{139}$.

In the twentieth century, the growing involvement of States in commercial activities progressively eroded the absolute immunity doctrine $^{140}$. Reflecting these changes, the Swiss Federal Supreme Court considered that once a State enters the market place and acts like a

133 B.S. Vasani; D.E. Vielleville, Esq.; 'Sovereignty Over Natural Resources Versus Rights Under Investment Contracts: Which One Prevails?' (2008), 2, TDM. < www.transnationaldispute management.com/article.asp?key=1211> accessed 23 June 2015.

134 Ibid.

135 Ibid.

136 General Assembly resolution 1803 (XVII) of 14 December 1962, "Permanent sovereignty over natural resources < http://www.ohchr.org/Documents/ProfessionalInterest/resources.pdf $>$ accessed 30 July 2015.

137 Hassan Sedigh, 'What Level of Host State Interference Amounts to a Taking under Contemporary International Law' (2001) 2 J. World Investment 631, 638.

138 B.S. Vasani; D.E. Vielleville, Esq (n 127).

139 Ibid.

140 Lew, Mistelis and Kröll (n 24) 744. 
private party, there is no more justification for allowing that State to avoid the economic consequences of its actions ${ }^{141}$. The trade-off is properly described by Baade as follows:

The customary international law rule of sovereign immunity illustrates the central importance of state sovereignty in the modern world. The restrictive theory of such immunity, on the other hand, demonstrates the need to accommodate respect for foreign sovereign rights to new circumstances, such as state trading. As there is 'no clear cut dividing line between acts done 'jure imperii' and acts done 'jure gestionis', one must consider what indicators are available as to whether an act is jure imperii or jure gestionis and the focus is on the nature of the act, or by analogy, the dispute ${ }^{142}$.

The next section will examine the limits on the use of sovereignty as a justification to deny arbitrability of certain disputes.

\subsubsection{Jure imperii acts and jure gestionis acts}

In public international law, the competence of States in respect of their territory is usually described in terms of sovereignty and jurisdiction. While jurisdiction refers to the ability of a State to exercise control over people, sovereign immunity refers to the idea that the actions of a foreign State lie outside the jurisdictional competence of other States ${ }^{143}$. Whilst initially sovereign immunity was much broader, a doctrine of restrictive immunity has developed and distinguishes between jure imperii acts (governmental acts) and jure gestionis acts (acts relating to the commercial activities of the State) ${ }^{144}$.

A State may reasonably expect to be immune from legal proceedings in a foreign court only in relation to its sovereign activities, while no immunity exists for activities of a purely commercial and private nature. ${ }^{145}$ Furthermore, under the doctrine of restrictive immunity, the concept of waiver of immunity was extended and it is

141 Ibid.

142 Hans W Baade, The Operation of Foreign Public Law (30 Tex Intl LJ.. 1995) 440 (as cited in Brazier (n 25) 17).

143 Ibid 14.

144 Ibid.

145 Mohamed AM Ismail, Globalization and New International Public Works Agreements in Developing Countries: An Analytical Perspective (Ashgate Pub 2011) 157. 
no longer necessary that a State expressly waive its immunity after the dispute has arisen; waiver can be obtained in advance. ${ }^{146}$

In commercial arbitration, the arbitration is endorsed by the State as 'private', based on its determination to respect the autonomous decisions of non-State actors to displace the courts' competence, though a mutually constructed alternative ${ }^{147}$. The authority for commercial arbitration and for the power to define lex mercatoria as a source of law originates from the State's choice to withdraw a particular dispute or contractual relationship from the primary jurisdiction of the courts and subject it to arbitration ${ }^{148}$.

The principle of sovereignty is the cornerstone of the power of the State to enact tax law ${ }^{149}$. Conventionally, taxation issues have been viewed as indivisible from State sovereignty, since it directly implies the funding by which governments operate, so it is understandable that national courts seek a monopoly on litigation of such a vital sovereign prerogative ${ }^{150}$. This attachment to State sovereignty is also the prevailing view about activities related to natural resources.

Major energy projects typically involve a long-term contract between a host State and an investor, under which the State grants a privilege to conduct an enterprise for a defined period ${ }^{151}$. The State transfers to the concessionaire or lessee certain powers that normally would belong to the State, but retains ultimate ownership of the right, which makes these contracts partly public and partly private in nature ${ }^{152}$. While some acts of a State related to exploration of natural resources may be considered jure imperii, States also undertake a variety of commercial activities that do not directly involve their sovereignty. This requires defining the parameters of sovereignty defence, in order to ensure that the scope of arbitrability is not too wide or narrow ${ }^{153}$.

Brazier took the example of investor-State taxation disputes in international commercial arbitration to advocate that sovereignty does not inhibit the arbitrability of all taxation disputes between investors

146 Lew, Mistelis and Kröll (n 24) 745.

147 Gus Van Harten, 'The Public-Private Distinction in the International Arbitration of Individual Claims against the State' (2007) 56 International \& Comparative Law Quarterly 372 $<$ http://www.journals.cambridge.org/abstract_S0020589300070159> accessed 14 July 2015. 148 Ibid.

149 Edwin van der Bruggen, 'State Responsibility under Customary International Law in Matters of Taxation and Tax Competition' (2001) 29 Intertax 115, 120.

150 William W Park, 'Arbitrability and Tax' [2009] Arbitrability: International and Comparative Perspectives 19,180 .

151 Brazier (n 25) 5.

152 Ibid.

153 Ibid 17. 
and States ${ }^{154}$. Rather, there is a distinction to be drawn between taxation disputes that directly imply sovereignty of States and are not arbitrable, and disputes as to taxation that are merely contractual in nature, only indirectly involving sovereignty, and thus are arbitrable ${ }^{155}$.

Brazier accentuates the difference between disputes that involve the direct exercise of sovereign authority (e.g., substantive tax law matters), and those that involve the indirect recognition of its effect on private or commercial relationships (e.g., the application of specific contractual standards) ${ }^{156}$. She gives the example of a provision stating that a tax payable on income is capped at a certain rate, what may raise substantive tax law issues, such as what constitutes income. This determination would involve a direct exercise of the State's sovereign authority over tax law. However, if the parties agreed as to what constitutes income, compliance with this kind of provision will be arbitrable, since this involves merely the indirect effect of a tax law, in order to assess compliance with the contract. By following this distinction, Brazier supports that stabilization provisions are arbitrable, because they involve questions of compliance with the contractual standard, since a State cannot disregard its promise of a stable framework. ${ }^{157}$

This framing is useful to examine contractual problems in disputes involving concession agreements in the oil and gas industry, such as the one that arose in the Lula case. In that case, the discussion hinges on the concept of "oil field" and the consequent amount of government take payable under the category of "special participation". This is owed when there is high volume of hydrocarbons or high profit margin ${ }^{158}$, and the rate varies from $10 \%$ to $40 \%$, applying on sales revenue adjusted by deductions allowed by law. ${ }^{159}$

The rationale in the Lula case is similar to Lauren Brazier's approach to taxation disputes. The concessionaires argued that the ANP breached the contract in order to increase revenues, since the concept of "oil field", in discussion, was incorporated in the concession agreement. Thus, the dispute would be arbitrable, because it is founded on the economic consequences of the State's interpretation of the concession agreement and because the State reneged on its promise of a stable framework.

In opposition, the ANP argued that a provision stating that the

154 Ibid 2.

155 Ibid 16.

156 Ibid 15.

157 Ibid 16.

158 KPMG Auditores Independentes. 'A Guide to Brazilian Oil and Gas Taxation' (2011)

$<$ http://www.kpmg.com/br/pt/estudos_analises/artigosepublicacoes/paginas/brazilian-oil-gastaxation.aspx $>$ accessed 29 July 2015.

159 Law 9,478/97, Decree 2,705/98 and ANP Edicts 10/99 and 102/99. 
government take is payable in a certain amount may raise substantive law issues, such as what constitutes an "oil field". The definition of "oil field" determines the amount of special participation that the concessionaries have to pay, since the bigger the area considered as a field, the bigger the production and higher the rate of special participation due. The ANP contended that the definition of "oil field" in the concession agreement could only be made by the State, because regulation is strictly related to sovereignty. This argument was accepted by the court ${ }^{160}$.

Nevertheless, there are decisions in Brazilian courts that clearly recognize the differences between the diverse activities that the State exercises and the public interest involved in each case, conferring distinct treatment to them. For example, in Brazil, the Public Attorney's Office needs to intervene in cases involving non-disposable rights. There are various decisions, however, holding that for the effect of such intervention, certain interests of governmental entities are not non-disposable, making a distinction between the public interest and pecuniary rights, so that governmental entities may not invoke the public interest to avoid the duty to indemnify damages caused. This was the gist of the decision by the justice Minister Luiz Fux ${ }^{161}$, which held that the State, when honouring its responsibility, and paying the corresponding indemnification, places itself in the position of serving the 'public interest'. On the other hand, when it evades its responsibility under concern for minimizing its pecuniary losses, it clearly pursues a secondary interest, subjectively pertaining to the state apparatus, engendering enrichment at the cost of damage to others. Moreover, the doctrine and jurisprudence are settled that the public interest is inalienable, but not the interest of the government and, in this last situation, the intervention of the Public Attorneys Office is not considered necessary.

\section{THE DECISION IN LULA CASE: A CRITICAL APPROACH}

\subsection{The decision on the jurisdiction}

Despite the judge's finding in the Lula case that national courts have jurisdiction to analyse jurisdiction during arbitration proceedings, the topic is controversial in Brazil. In other recent case ${ }^{162}$, the ANP also

$1601^{\text {st }}$ Federal Court of the Judiciary Section of Rio de Janeiro (n 14).

161 Superior Tribunal of Justice, Special Appeal no.1153076/GO, $1^{\text {st }}$ Panel, Reporting Justice Luiz Fux, judged on 16 March 2010, published in the DJ of 29 March 2010.

$1625^{\text {th }}$ Federal Court of the Judiciary Section of Rio de Janeiro. Ordinary Action no.000680084.2014.4.02.5101, Justice Sergio Bocayuva Tavares de Oliveira Dias, judged on 01.10.2014 published in the DJ (Court Reporter) of October 16, 2014. 
rejected concessionaires' development plans, for the same reason of the blurred concept of "oil field", and similar disputes arose.

In the case of the Baleias ("Whales") field ${ }^{163}$, the development plan was denied and the concessionaire started arbitration before the ICC, prompting the ANP to file an injunction action in national courts aiming to stop the arbitration. In this case, however, the decision of another federal court ( $5^{\text {th }}$ Federal Court of Rio de Janeiro) was completely different from the one given in Lula case.

The judge of the $5^{\text {th }}$ Federal Court decided that art. 25 of the BAA, which ANP invoked to support prior judicial definition of jurisdiction, does not indicate that the judiciary should rule in advance. Instead, the Court decided that there is a first assessment to be made by arbitration. In addition, the judge continued, Article 25 deals with the procedure to be adopted in cases where the inalienable right appears as a prejudicial question, not as the main subject matter. Thus, the situation discussed attracts application of Article $20^{164}$ of the BAA, so the claim of lack of jurisdiction mustbe addressed to the arbitral tribunal, at the first opportunity, after the commencement of the arbitration. According to paragraph 2 of Article 20, with the rejection of the claim by the arbitral tribunal, the arbitration shall proceed normally, with the possibility of contesting the award in court only by way of an annulment action for setting aside the award $^{165}$. Thus, the judge held that rules on the relationship between jurisdiction and arbitration are to be examined by the judiciary only at the end ${ }^{166}$, a solution opposed to the one given in Lula case.

The concessionaries then argued that the ANP did not obey the judicial decision related to the Whales field, so they filed an action called "Conflict of Competence"167, directly to the STJ. The conflict is between the Brazilian state court and the arbitral tribunal constituted under the Rules of the ICC, by deciding on the validity and existence of the arbitration clause inserted on the concession contract signed between the concessionaire and the ANP.

163 Ibid.

164 Article 20, BAA states 'The party wishing to raise issues related to the jurisdiction, suspicion or impediment of an arbitrator or arbitrators, or as to the nullity, invalidity or ineffectiveness of the arbitration agreement, must do so at the first opportunity, after the commencement of the arbitration. $\S 1$ When the challenge is accepted, the arbitrator shall be replaced in accordance with Article 16 of this law; and if the lack of jurisdiction of the arbitrator or of the arbitral tribunal, as well as the nullity, invalidity or ineffectiveness of the arbitration agreement is confirmed, the parties shall revert to the State Court competent to rule on the matter; $\S 2-$ When the challenge is not accepted, the arbitration shall proceed normally, subject however to review of that decision by the competent State Court if an action dealt with in Article 33 of this Law is filed'.

165 Article 33, BAA.

$1665^{\text {th }}$ Federal Court of the Judiciary Section of Rio de Janeiro (n 158).

167 Superior Tribunal of Justice (n 8). 
The reporting judge assigned to the conflict of competence case, Judge Nancy Andrighi, noted:

The promulgation of Law 9,307/96 made it necessary to preserve, to the greatest extent possible, the authority of the arbitrator as the de facto and de jure judge for questions linked to the merit of the cause. Rejecting that provision would empty the hollow out the Arbitration Law, permitting the same right to be considered simultaneously, even if in perfunctory form, by the state court and arbitral court, often with serious possibilities of conflicting interpretations of the same facts ${ }^{168}$.

The STJ primarily considered itself to be competent to settle conflicts of competence between State courts and arbitral tribunals. It also stressed that it is essential that the powers of the arbitrators be preserved and stated that until a final decision is rendered regarding the dispute, the arbitral tribunal has competence to rule over urgent and provisional measures between the parties, and every administrative or judicial proceeding against the concessionaire, present or future, shall be stayed ${ }^{169}$.

Therefore, Brazilian courts have not yet reached a definitive decision on the jurisdiction to determine arbitrability. The pending decision in the conflict of competence action in the case of the Baleias field, despite having its direct effects only on the object in dispute, will provide an important precedent and help to construct jurisprudence in this regard. Meanwhile, one can notice that the first instance decisions in the Lula case and Baleias case, although based on similar facts, were absolutely totally different.

\subsection{The decision on arbitrability}

The federal court's decision in the case of Lula field took into consideration that the clause 1.26 of the concession agreement ${ }^{170}$ expressly states that the legal definition of 'oil and natural gas field' is incorporated into the contract, by stating that 'field' has the same meaning as 'oil and natural gas field', as defined in the Brazilian Petroleum Law. It states that for the purposes of this Law and its regulation, Oil or Natural Gas Field is the area producing oil or natural gas from a continuous reservoir or more than one reservoir at variable

168 Ibid.

169 Ibid.

170 National Petroleum, Natural Gas and Biofuels Agency (n 13). 
depths, including the facilities and equipment intended for production ${ }^{171}$.

The concessionaire argued that after exploring the area, two fields were discovered, named "Lula" and "Cernambi". Given these findings, the operator submitted to two different development plans and two declarations of commerciality to the ANP, since they were separate fields from a geological standpoint ${ }^{172}$. The judge of the First Federal Court of Rio de Janeiro ${ }^{173}$ considered that the decision on definition of fields falls under the ANP's supervisory remit, resulting from the police power, stated in Article 78 of the National Tax Code ${ }^{174}$. The judge held that the decision was taken under the discretionary power available to the public administration, so recourse to arbitration encroaches on the imperatives of administrative acts ${ }^{175}$.

The question that arises is to what extent a government may affect a private right, even for a legitimate public purpose, by regulation, either general in nature or by specific actions, without having to pay compensation ${ }^{176}$. Approving or denying the development plan can be considered an act of state sovereignty. However, there is another view that even being sovereign, the act generates pecuniary damages and frustrates the expectations of the concessionaires. Since the concept of "oil field" was incorporated in the contract, the unpredictability of the interpretation could have caused pecuniary damages to the oil companies, which would be arbitrable.

During the course of the Middle East oil nationalizations, some governments invoked their domestic law to allege that concessions were administrative contracts. In countries inspired by French administrative law, a contract may include exorbitant clauses allowing the government to amend or modify the service provider's obligations. Accordingly, States argued that concession agreements, as administrative contracts, were subject to the changes and modifications within the State's policy powers ${ }^{177}$.

The arbitral awards issued in the 1970s followed the wave of unilateral government actions and tested the contract-based stability

171 Article 6, Brazilian Petroleum Law.

172 The ANP said there was only one field, since the concept of Oil Field defined in article 6 of the Brazilian Petroleum Law has no geological nature and allows more than one reservoir to be included in a single field. However, the ANP argued that the application of the concept of "oil field" would only be possible in the occurrence of vertically overlapping reservoirs, instead of several reservoirs within a block granted by contract.

$1731^{\text {st }}$ Federal Court of the Judiciary Section of Rio de Janeiro (n 14).

174 Brazilian Law 5,172/1966.

$1751^{\text {st }}$ Federal Court of the Judiciary Section of Rio de Janeiro (n 14).

176 OECD, "Indirect Expropriation" and the "Right to Regulate" in International Investment Law' (2004) OECD Working Papers on International Investment 2004/04 $2<\mathrm{http}$ ://www. oecd-ilibrary.org/finance-and-investment/indirect-expropriation-and-the-right-to-regulate-ininternational-investment-law_780155872321> accessed 25 July 2015.

177 D.E. Vielleville, Esq. and B.S. Vasani (n 127). 
mechanisms developed by investors in the preceding years ${ }^{178}$. In LIAMCO $v$ Libya ${ }^{179}$, the arbitrator decided that both under Libyan law and UN Resolutions, a State possesses, as an attribute of its sovereignty, the right to nationalize all things belonging to any person in its jurisdiction, if such a measure is not discriminatory and is for a legitimate public purpose. In the LIAMCO case, the arbitrator held that although the nationalization was for economic reasons, the right contrasted with the principle of pacta sunt servanda, accepted under Libyan law and recognized as an international custom and case law precedent ${ }^{180}$.

In the case of Texaco vs Lybia ${ }^{181}$, the sole arbitrator held the Libyan nationalization measures to ineffective with respect to an international contract ${ }^{182}$. The award listed three tests of internationalization of investment agreements, any one of which was said to suffice: an agreement to arbitrate; reference to general principles of law or international law as the applicable law; or that the agreement be an economic development agreement ${ }^{183}$.

Published arbitral awards have not tackled the legality and binding nature of stabilization clauses restricting the right to regulate, and the repercussion of regulatory changes not amounting to expropriations ${ }^{184}$. Nevertheless, it is certain that states cannot invoke domestic law rules to violate its obligations, and this may include outright expropriation in breach of a clause, or regulatory change in breach of a clause. In the case of economic equilibrium clauses, parties are under an obligation to negotiate in good faith so as to restore the economic equilibrium following regulatory change, and, in this context, payment of compensation emerges as the main legal effect of such breaches ${ }^{185}$.

Patrick Wautelet observes that the application of international law does not exclude possibility of a contract also being governed by national law, if the parties expressly indicated their choice for such a law, but the application of national law does not hinder the application of international law ${ }^{186}$.

178 Peter D Cameron, International Energy Investment Law: The Pursuit of Stability (Oxford University Press 2010) 104.

179 Libyan American Oil Company (Liamco) v. The Government of the Libyan Arab Republic, [1977] 62 I.L.R 140.

180 Cameron (n 178) 119.

181 Texaco Overseas Petroleum Company and California Asiatic Oil Company v. The Government of the Libyan Arab Republic, [1977] 53 I.L.R. 389.

182 DeVries (n 93) 76.

183 Ibid.

184 Organisation for Economic Co-operation and Development, OECD Investment Policy Perspectives 2008 (OECD 2008) $74<$ http://public.eblib.com/choice/publicfullrecord. aspx? $\mathrm{p}=432557>$ accessed 29 July 2015.

185 Ibid.

186 Patrick Wautelet, 'International Public Contracts: Applicable Law and Dispute Resolution' 
The significance of the protection against expropriation is not primarily protection against outright seizure of investments by the host country, but rather the protections against various forms of indirect or creeping expropriation such as regulations or confiscatory taxation that undermine the operation or enjoyment of the investment ${ }^{187}$. Indeed, it is accepted as a principle of international law, normally referred to as police power or eminent domain, that a sovereign State has the right to regulate the economic and commercial activities in its territory. However, it is questionless this right is not unqualified and State regulation cannot be unlimited ${ }^{188}$.

\subsection{An international approach to State acts and protection of investors in the oil and gas industry}

\subsubsection{Substantive considerations on the Lula case}

The judicial decision in the Lula case was limited to the ANP's claim to stop the arbitral proceeding based on the arguments that national courts have jurisdiction and that the right in dispute is not disposable ${ }^{189}$. Nevertheless, once the jurisdiction to settle the conflict is defined, a decision is to be given on the merits, about whether some kind of damage was caused by the State act and whether any kind of compensation is owed to the concessionaire.

Some issues will be theoretically considered here, by analyzing concerns that arises from the case and the need to manage this kind of dispute. The issues below are considered in order to examine State duties in the oil and gas industry, taking into consideration that it is an international industry.

As set out before, in the Lula case, the denial of the development plan by the ANP resulted from the definition of oil field, since the concessions agreement defines "oil field" as stated in the Brazilian Petroleum Law and the concept provided in the Brazilian Petroleum Law gives certain margin of discretion. However, as already recognized by the ANP, in previous cases ${ }^{190}$, a precise definition became necessary to provide transparency for the contract.

[2013] THE INTERNATIONALIZATION OF PUBLIC CONTRACTS $6<$ http://orbi.ulg. ac.be/handle/2268/136404> accessed 19 July 2015.

187 K Hober, 'Investment Arbitration and the Energy Charter Treaty' (2010) 1 Journal of International Dispute Settlement 153, 161.

188 OECD (n 176) 681.

$1891^{\text {st }}$ Federal Court of the Judiciary Section of Rio de Janeiro (n 14).

190 In the Technical Note n 103/2014/SDP, Administrative Process 48610.003426/2013-96, ANP recognized the necessity to increase the transparency and made a recommendation for the definition the concept of "oil field" <www.anp.gov.br/?dw=71448> accessed 30 July 2015. 
Although some acts are considered jure imperii, this does not mean they can be arbitrary. The definition needs to be clearly established in advance to provide predictability for the investor. Brazil needs to strengthen transparent regulation of this subject in order to avoid discussions about legal concepts. Otherwise, the changing of interpretation or the failure of the State to provide an unambiguous contract clause can cause damages to private parties, which may require some sort of compensation. As explained before, the concept of field directly influences the amount of the government take, making it an essential concept that must be clearly determined beforehand.

The failure to clarify technical concepts can even prove to be contrary to good faith, since the regulatory agency shall act reasonably and in a prompt and timely manner, based on the efficient and economic conduct of petroleum operations and in accordance with good international oil industry practices ${ }^{191}$.

Another question to be investigated is whether the governmental measure affects the investor's reasonable expectations. The investor must demonstrate that the investment was based on circumstances that did not include the challenged regulatory regime and the assertion must be objectively reasonable and not based entirely upon the investor's subjective expectations ${ }^{192}$.

According to Frederico Favacho, these conflicts must be minimized and resolved by a competent conflict management system, whether in a preventive way, as the search for clear contracts containing transparent, uniform and unambiguous terms, whether by use of an supra state norms, as the principles of UNIDROIT and Lex petrolea and with the adoption of arbitration as the best means of solution available to the parties ${ }^{193}$.

Traditionally, private international law includes the law of conflict resolution, by indicating the conflicting rule. However, soft law arose as an attempt to establish a uniform law for substantive rules on certain matters, understood as a complex of rules to justify decisions or to legitimize practices and behaviours typical of a professional nature, in the field of international trade ${ }^{194}$. These rules, although not expressly stated in the agreement signed between the parties, identify possible solutions of conflicts in such a way that the contracting parties, in anticipation of the expected result, can previously settle the conflict,

191 Cameron (n 178) 67.

192 OECD (n 176) 19.

193 Frederico Favacho, 'A GESTÃO DE CONFLITOS EM CONTRATOS INTERNACIONAIS DO PETRÓLEO’ (2011) 18 Revista Brasileira de Direito Constitucional-RBDC n 243, 243. 194 Clause 31.5 of the concession contract for Lula field ( $2^{\text {nd }}$ Bidding Round) says that the ANP must, whenever it exercises its discretionary power, act justifiably, while observing applicable legislation, as well as Oil Industry Best Practices. 
preventing wear and higher costs ${ }^{195}$.

\subsubsection{Considering the existence of a lex petrolea}

The term 'lex petrolea' entered the legal lexicon and the international oil and gas industry more than a quarter of a century ago. The term first emerged in a landmark international arbitration case in 1982, which concluded in favor of the existence of a "customary rule valid for the oil industry - a lex petrolea that was in some sort a particular branch of a general universal lex mercatoria. " 196 Tim Martin wrote that:

This analysis supports the thesis that a lex petrolea has developed over the years, but widens the scope of inquiry to the full range of disputes encountered in the international arbitration and court cases. However, it has also developed in a number of other forums, from government's petroleum legislation and contracts to the industry's business practices, which are found in its model contracts ${ }^{197}$.

Lex petrolea is most often established from decisions arising from disputes within the international oil and gas sector, as this is where the contracts, legislation and treaties that affect the petroleum sector are tested and interpreted ${ }^{198}$. Unlike the courts, the world of international arbitration is not bound by precedent, although arbitrators make their decisions in a context. Since counsel use precedents in arguing their cases and arbitrators refer to precedents in writing their awards, a lex petrolea has developed accordingly. ${ }^{199}$

Although the decisions do not have a unity of opinion in the international community as to create anything like blackletter law rules, immense progress has been made in the past 25 years, so that in some petroleum issues, clear legal rules have evolved, while in others at least the proper range of rules has been identified. The beginnings of a lex petrolea serve to instruct, and in a certain sense even regulate, the international petroleum industry ${ }^{200}$. Then, even when a arbitration agreement chooses to apply the national law in substantive matters, the

195 Favacho (n 193) 259.

196 Tim Martin 'Lex petrol ea in international law' in Ronnie King, Dispute Resolution in the Energy Sector: A Practitioner's Handbook (Globe Law and Business 2012) 95.

197 Ibid 95.

198 Ibid 96.

199 King (n 196). 95.

200 Albert Jan Van den Berg, Yearbook Commercial Arbitration 1994 Vol. XIX Vol. XIX (Kluwer Law International 1994). 
principles already constructed by lex petrolea shall be considered.

\subsubsection{Pursuing stability}

Legalarrangements are important to protectinvestors entitlements and to ensure stability of the regulatory framework governing their activities, since investor is vulnerable to host government action that may undermine the financial viability or even expropriate the investor's assets altogether ${ }^{201}$.

Stabilization clauses aim to stabilize the terms and conditions of an investment project, thereby contributing to the management of noncommercial risk. They involve a commitment by the host government not to alter the regulatory framework governing the project, by legislation or any other means, outside specified circumstances ${ }^{202}$. More recent stabilization clauses have evolved into various and sophisticated tools to manage non-commercial risk associated with the investment project $^{203}$

Stabilization clauses are particularly common in large natural resource, energy and infrastructure projects, where high fixed costs demand huge capital outlays in the early stages of the project and long timeframes are necessary to reach the breakeven point ${ }^{204}$. Their scope has tended to broaden, to include stabilization of specific aspects of the project, such as its fiscal regime and other broad commitments to stabilize the regulatory framework governing the investment ${ }^{205}$.

Economic equilibrium clauses are another type of stabilization mechanism, which link changes of the terms of the contract to renegotiation to restore its original economic equilibrium or payment of compensation. Unlike freezing clauses, economic equilibrium clauses stabilize the economic equilibrium of the contract rather than the regulatory framework itself. Therefore, regulatory changes are possible as long as the economic balance is restored ${ }^{206}$.

Economic equilibrium clauses protect against less intrusive forms of government action that affect the cost-benefit equilibrium of the investment, which includes legislation, the judicial or administrative interpretation of existing provisions, and other measures that influence

201 Organisation for Economic Co-operation and Development (n 184) 70.

202 Ibid 72.

203 Ibid 8.

204 L Cotula, 'Reconciling Regulatory Stability and Evolution of Environmental Standards in Investment Contracts: Towards a Rethink of Stabilization Clauses' (2008) 1 The Journal of World Energy Law \& Business 158, 160.

205 Ibid.

206 Ibid. 
the economic balance and would prompt some sort of compensation ${ }^{207}$.

In addition, the legal value of stabilization clauses may be reinforced by provisions in investment treaties, whereby a State commits itself to honour contractual undertakings of nationals of another state party ("umbrella clause") ${ }^{208}$. Indeed, the very nature of this kind of investor-State dispute resolution system is a limitation of State sovereignty, as the host government sacrifices some freedom of action in exchange for increased flows of foreign direct investment ${ }^{209}$.

Unfortunately, Brazil is not signatory to any investment treaty that protects foreign investors and provides broader coverage than an investment agreement ${ }^{210}$. Nevertheless, foreign companies can participate in Brazilian bidding rounds, and acquire the right to explore and produce oil and gas in the tendered areas. The Brazilian Petroleum Law also states that "attracting investments in energy production" and "promoting the growth of the country's competitiveness in the international market", as objectives of the "national policies for the rational utilization of the energy sources" 211.

The contract may also require the parties to perform it consistently in good faith, since this duty is itself a general principle of law as well as a basis for a prohibition of unjust enrichment and of the rule that a State entity cannot rely upon a change of law to excuse a breach of contract. It can act as a way of bringing international law principles, based upon reason and the practice of civilized countries ${ }^{212}$.

When applying the principle of fair and equitable treatment, tribunals consider other principles such as the protection of legitimate investor expectations with respect to the maintenance of a stable and predictable legal environment by the host government, the principle of transparency, good faith, due process, proportionality and the prohibition on arbitrariness ${ }^{213}$. Not only tribunals, but also courts and authorities of the host State must observe prohibition of arbitrariness and requirements of transparency, which fall under the general framework of due process ${ }^{214}$.

Therefore, State activities related to the oil and gas industry in Brazil should offer guarantees to investors and pursue a stable scenario for investments, both national and international ones, such since these principles of protection are already instituted in international practice.

207 Ibid 167.

208 Ibid 163.

209 Rubins (n 118) 1087.

210 Ibid 1088.

211 Article 1, Law 9,478/97.

212 Cameron (n 178) 67.

213 Hober (n 187).

214 Ibid 158. 


\section{Conclusion}

Important issues were discussed related to jurisdiction, applicable law and arbitrability, in order to clarify the functioning of arbitration. For matters related to arbitrability and public policy, the main difficulty arises in cases where the State presents a public policy argument as an objection against jurisdiction of arbitral tribunals, by saying the right is not disposable. The BAA contains important exceptions to enforcement of foreign arbitral awards, similar to the grounds for non-enforcement of arbitration agreements. In particular, Brazilian courts are authorized to refuse recognition and enforcement to any award that violates Brazilian sovereignty, public morals, or policy ${ }^{215}$.

Regarding exploration and production of oil and other natural resources, the major issues involving the State and investors took into consideration the issues that arose in the Lula case. Although some regulatory acts have sovereign nature, the oil and gas industry is an international one, and some international standards need to be considered in order to protect investors and guarantee a predictable and level playing field.

Because the investor does not have the benefit of Article 26 of the Washington Convention, which established the ICSID, it may be difficult to compel Brazil to participate in arbitration proceedings and to keep the government from suing the investor on the same dispute in Brazilian courts ${ }^{216}$. It is still unpredictable how Brazilian courts will deal with arbitrations involving the State, especially agencies of the direct administration, considering the issues of politics and national sovereignty involved, although as explained in chapter 7.2, there is a conflict of competence case pending decision by the STJ that will serve as a guide to decide cases similar cases.

It is necessary to provide a proper environment for investment and to balance public and private interests. State's concerns with collecting higher revenues cannot override the security of investors. The main concerns and challenges are improving legislation and contracts and giving effectiveness to arbitration clauses, through judicial and administrative measures.

To conclude, it is worth citing Mauricio Gomn, a student in the LL.M. course at Queen Mary and Westfield College (University of London). He told that in his personal presentation on his first day of class (12 October 1992), Professor Julian D.M. Lew kindly asked him, "Are you sure you are in the right classroom?", surprised that the School of International Commercial Arbitration was receiving a Brazilian student for the first time. The professor asked: "Is this a sign that things

215 Rubins (n 118).

216 Ibid. 
are changing in Brazil? ${ }^{217}$ ",

The answer is yes, many things have changed in Brazil since then. In 1992, the year that Mauricio attended Queen Mary and Westfield College, exploration and production of oil and gas were still a State monopoly, exercised exclusively by Petrobras. In 1997, the Brazilian Petroleum Law ended the monopoly, enabling the participation of foreign companies in biddings of the tendered areas, and created the ANP. The first concession agreement was signed before the so-called Round Zero, in 1997, and since then the standard contract has contained an arbitration clause ${ }^{218}$, maintained in all the following bidding rounds until now. Due to all these changes, in 2015 many Brazilian students could attend arbitration classes at Queen Mary University, not only Commercial Arbitration classes, but also Energy Arbitration ones. Nevertheless, 23 years later, we still have many doubts about the way changes have been and should be applied in Brazil.

\section{REFERENCES}

C, 'Arbitrability and Tax' [2009] Arbitrability: International and Comparative Perspectives 19

- 'Arbitral Jurisdiction in the United States: Who Decides What?' (2008) 11 International arbitration law review 33

-, 'Dallah and the New York Convention' <http:// kluwerarbitrationblog.com/blog/2011/04/07/dallah-and-the-new-yorkconvention/> accessed 14 July 2015

_, 'The Law Applicable to Arbitrability' (2014) 26 Singapore Academy of Law Journal

- 'The Negative Effect of Competence-Competence: The Verdict Has to Be Negative' [2009] Austrian arbitration yearbook 238

1st Federal Court of the Judiciary Section of Rio de Janeiro. Ordinary Action no. 0005966-81.2014.4.02.5101, Justice Mauro Souza Marques da Costa Braga.

5 th Federal Court of the Judiciary Section of Rio de Janeiro. Ordinary Action no.0006800-84.2014.4.02.5101, Justice Sergio Bocayuva Tavares de Oliveira Dias.

BARCELO III JJ, 'Who Decides the Arbitrator's JurisdictionSeparability and Competence-Competence in Transnational Perspective'

217 Mauricio Gomm Ferreira dos Santos, 'Arbitration in Brazil' (2004) 21 Journal of International Arbitration 493, 453.

218 National Petroleum, Natural Gas and Biofuels Agency (ANP), Round Zero Concession Agreement $<\mathrm{http}$ //www.brasil rounds.gov.br/portugues/rodada_zero.asp > accessed 29 July 2015 . 
(2003) 36 Vand. J. Transnat'1 L. 1115

BARON PM and LINIGER S, 'A Second Look at Arbitrability: Approaches to Arbitration in the United States, Switzerland and Germany' (2003) 19 Arbitration International 27

BELOHLAVEK AJ, 'The Law Applicable to the Arbitration Agreement and the Arbitrability of a Dispute' [2013] Yearbook of International Arbitration, M. Roth and M. Giestlinger (eds.), Intersentia/DIKE/NWV, Antwerpen-Zurich-Vienna-Graz 27

BORN G, International Commercial Arbitration (Second edition, Kluwer Law International 2014)

BRAZIER L, 'The Arbitrability of Investor-State Taxation Disputes in International Commercial Arbitration' 32 Kluwer Law Online 1

Brazilian Arbitration Act (Law 9,306/97).

Brazilian Concession's Law (Law 8,987/ 1995).

Brazilian Federal Supreme Court, Regimental Appeal in Contested Foreign Judgment no. 5206, Reporting Justice Sepúlveda Pertence.

Brazilian Law 13,129/ 2015.

Brazilian Petroleum Law (Law 9,747/ 1997).

Brazilian Public Private Partnership Law (Law 11,079/2004).

BREKOULAKIS S, 'Law Applicable to Arbitrability: Revisiting the Revisited Lex Fori' <http://papers.ssrn.com/sol3/papers.cfm?abstract id $=1414323>$ accessed 15 July 2015

CAMERON PD, International Energy Investment Law: The Pursuit of Stability (Oxford University Press 2010)

COTULA L, 'Reconciling Regulatory Stability and Evolution of Environmental Standards in Investment Contracts: Towards a Rethink of Stabilization Clauses' (2008) 1 The Journal of World Energy Law \& Business 158

Dallah Real Estate and Tourism Holding Company v The Ministry of Religious Affairs, Government of Pakistan [2010] UKSC 46.

DEVRIES HP, 'International Commercial Arbitration: A Contractual Substitute for National Courts' (1982) 57 Tul. L. Rev. 42

DULIC A, 'First Options of Chicago, Inc. v. Kaplan and the KompetenzKompetenz Principle’ (2002) 2 Pepp. Disp. Resol. LJ 77

FAVACHO F, 'A GESTÃO DE CONFLITOS EM CONTRATOS INTERNACIONAIS DO PETRÓLEO’ (2011) 18 Revista Brasileira de Direito Constitucional-RBDC n 243 
Fincantieri- Cantieri Navali Italiiani and Oto Melara v. Mvand Arbitration Tribunal V, (1995) XX YBCA 766.

HANOTIAU B, 'La Loi Applicable a L'Arbitrabilite Du Litige' [1998] Int'l Bus. LJ 755

HARRIS TL, "The "Public Policy" Exception to Enforcement of International Arbitration Awards Under the New York ConventionWith Particular Reference to Construction Disputes' (2007) 24 Journal of International Arbitration 9

HOBER K, 'Investment Arbitration and the Energy Charter Treaty' (2010) 1 Journal of International Dispute Settlement 153

HSU L, 'Public Policy Considerations in International Arbitration: Costs and Other Issues A View from Singapore' (2009) 26 Journal of International Arbitration 101

ISMAIL MAM, Globalization and New International Public Works Agreements in Developing Countries: An Analytical Perspective (Ashgate Pub 2011)

JUNIOR JRD, 'RESPONSABILIDADE CIVIL DO ESTADO EM FACE DOS CONTRATOS ADMINISTRATIVOS: Possíveis Mecanismos de Preservação Ambiental E de Defesa Do Interesse Público' $\quad<$ http://www.bdtd.unitau.br/tedesimplificado/tde busca/ processaArquivo.php?codArquivo $=160>$ accessed 27 July 2015

KALICKI J and Medeiros S, 'Investment Arbitration in Brazil' (2008) 24 Arbitration International 423

KAPLAN, Neil ' Speech to the Franco-British Law Society in Paris in 2001 (19(2)Journal of International Arbitration 2002) in Quentin Tannock:, 'Judging the Effectiveness of Arbitration through the Assessment of Compliance with and Enforcement of International Arbitration Awards' 21 Arbitration International (2005).

KING R, Dispute Resolution in the Energy Sector: A Practitioner's Handbook (Globe Law and Business 2012)

KPMG Auditores Independentes. 'A Guide to Brazilian Oil and Gas Taxation' (2011) <http://www.kpmg.com/br/pt/estudos_analises/ artigosepublicacoes/paginas/brazilian-oil-gas-taxation.aspx $>-$ accessed 29 July 2015

LEVY D de A, BORJAAG de and PUCCIA(eds), Investment Protection in Brazil (Kluwer Law International 2014)

LEW JDM, Mistelis LA and Kröll SM, Comparative International Commercial Arbitration (Kluwer Law International 2003)

Libyan American Oil Company (Liamco) v. The Government of the 
Libyan Arab Republic, [1977] 62 I.L.R 140.

MARTIN T 'Lex petrol ea in international law' in Ronnie King, Dispute Resolution in the Energy Sector: A Practitioner's Handbook (Globe Law and Business 2012) 95

MOURRE A, 'Perspectives of International Arbitration in Latin America’ (2006) 17 Am. Rev. Int'l Arb. 597

MURIEL MA, 'A Arbitragem Frente Ao Judiciário Brasileiro' (2004) 1 Revista Brasileira de Arbitragem 27

NATIONAL PETROLEUM, NATURAL GAS AND BIOFUELS AGENCY (ANP), 2nd Biddind Round Concession Agreement $<$ http:// www.brasilrounds.gov.br/round2/arquivos_r2/Edital/Edital_en.pdf $>$ accessed 29 July 2015

NATIONAL PETROLEUM, NATURAL GAS AND BIOFUELS AGENCY (ANP), Round Zero Concession Agreement $<_{i}$ Error! Referencia de hipervínculo no válida. > accessed 29 July 2015

OECD, "Indirect Expropriation" and the "Right to Regulate" in International Investment Law' (2004) OECD Working Papers on International Investment 2004/04 <http://www.oecd-ilibrary.org/ finance-and-investment/indirect-expropriation-and-the-right-toregulate-in-international-investment-law_780155872321> accessed 25 July 2015

OLIVEIRA LVP de and MIRANDA I, 'International Public Policy and Recognition and Enforcement of Foreign Arbitral Awards in Brazil' 30 Journal of International Arbitration 201349

ORGANISATION FOR ECONOMIC CO-OPERATION AND DEVELOPMENT, OECD Investment Policy Perspectives 2008 (OECD 2008) <http://public.eblib.com/choice/publicfullrecord. aspx? $\mathrm{p}=432557>$ accessed 29 July 2015

PARK WW, 'The Arbitrability Dicta in First Options v. Kaplan: What Sort of Kompetenz-Kompetenz Has Crossed the Atlantic?' (1996) 12 Arbitration International 137

Parsons \& Whittemore Overseas Co. Inc. v Soceite Generale de l'Industrie du Papier (RAKTA) 508 F.2d 969 (2nd Cir. 1974).

PIERCE KR, 'Down the Rabbit Hole: Who Decides What's Arbitrable?' (2004) 21 Journal of International Arbitration 289

RIGOZZI A, 'Provisional Measures in CAS Arbitrations" (1984) 2004 Blackshaw, Siekman and Soek. The Court of Arbitration for Sport 227

RUBINS ND, 'Investment Arbitration in Brazil' (2003) 4 J. World Investment 1071 
SANTOS MGF dos, 'Arbitration in Brazil' (2004) 21 Journal of International Arbitration 493

SEDIGH H, 'What Level of Host State Interference Amounts to a Taking under Contemporary International Law' (2001) 2 J. World Investment 631

Superior Tribunal of Justice, Special Appeal no.1153076/GO, 1st Panel, Reporting Justice Luiz Fux.

Superior Tribunal of Justice. Conflict of Competence no. 139.519 - RJ (2015/0076635-2), Reporting Justice Nancy Andrighi.

Switzerland's Federal Code on Private International Law (CPIL)1 of December 18, 19872.

The Convention on the Recognition and Enforcement of Foreign Arbitral Awards (adopted 10 June 1958 entered into force 07 June 1959) 330 UNTS 38 (1968).

TOMIMATSU $\mathrm{C}$ and Cattel $\mathrm{M}$, 'The Recent Amendments to the Brazilian Arbitration Act - One Step Back, Two Steps Forward?' < http:// kluwerarbitrationblog.com/blog/2015/06/30/the-recent-amendmentsto-the-brazilian-arbitration-act-one-step-back-two-steps-forward/> accessed 14 July 2015

U.S. Supreme Court, First Options of Chicago, Inc. v. Kaplan (94-560), 514 U.S. 938 (1995).

U.S. Supreme Court, Mitsubishi v. Soler Chrysler-Plymouth, 473 U.S. 614 (1985).

UNCITRAL Model Law on International Commercial Arbitration 24 ILM 1302 (1985).

VAN DEN BERG AJ, Yearbook Commercial Arbitration 1994 Vol. XIX Vol. XIX (Kluwer Law International 1994)

VAN DER BRUGGEN E, 'State Responsibility under Customary International Law in Matters of Taxation and Tax Competition' (2001) 29 Intertax 115

VAN HARTEN G, 'The Public — Private Distinction in the International Arbitration of Individual Claims against the State'(2007) 56 International \& Comparative Law Quarterly <http://www.journals.cambridge.org/ abstract_S0020589300070159> accessed 14 July 2015

VASANI B.S.; Vielleville D.E., Esq.; 'Sovereignty Over Natural Resources Versus Rights Under Investment Contracts: Which One Prevails?' (2008), 2, TDM

WAUTELET P, 'International Public Contracts: Applicable Law and 
Panor. Braz. law - Vol 4, Nos. 5 and 6 (2016)

Dispute Resolution' [2013] THE INTERNATIONALIZATION OF PUBLIC CONTRACTS <http://orbi.ulg.ac.be/handle/2268/136404> accessed 19 July 2015

WYSS N, 'First Options of Chicago, Inc. v. Kaplan: A Perilous Approach to Kompetenz-Kompetenz' (1997) 72 Tul. L. Rev. 351. 